\title{
Analysis on the Export Competitiveness of Shenzhen High-tech Products
}

\author{
Xi YANG ${ }^{1 \mathrm{a}}$ Ming $\mathrm{LUO}^{1 \mathrm{~b}}$ \\ ${ }^{1}$ Institute of finance and economics, \\ Cross-border e-commerce research institute \\ Guangdong University of Science and Technology \\ 523083 Dongguan, Guangdong, China
}

\begin{abstract}
The export scale of Shenzhen has been ranked first in large and medium-sized cities in mainland China for $\mathbf{2 6}$ consecutive years, among which the export of high-tech products has been relatively stable. This paper analyzes the development of high-tech industry in Shenzhen, the power and support provided by scientific and technological investment and technological innovation, the ways to improve the export competitiveness of products in Shenzhen, and summarizes the law of sustainable development which can help to promote the export competitiveness of high-tech products in Shenzhen.
\end{abstract}

\section{INTRODUCTION}

In the past 40 years of China's reform and opening up, Shenzhen's high-tech industry has started from "zero", carried out institutional innovation around innovation, optimized business environment, laid a foundation for a long term, focused on key generic technology, leading technology, modern engineering technology and disruptive technology innovation, constantly consolidated and improved the advantages of innovation and development, and achieved the goal of staying behind.

Especially since 2011-2019, in accordance with the spirit of "four insistences, three supports and two leading positions", Shenzhen city has formulated and implemented the Shenzhen action plan of "Internet plus" and "made in China 2025". Shenzhen industry has continuously enhanced its ability of independent innovation, improved its quality and efficiency, and continued to advance to the requirements of high-quality development.

In 2019, the total volume of import and export of goods is 426.687 billion US dollars, second only to Shanghai in scale, and China continues to rank the second in large and medium-sized cities in the mainland. Among them, the total export volume is 252986 million US dollars, and the export scale ranks the first in mainland large and medium-sized cities for 26 consecutive years; the import volume is 1991.137 billion US dollars, and the import scale is the third in mainland large and medium-sized cities. The total export volume of high-tech products is 127.971 billion US dollars.

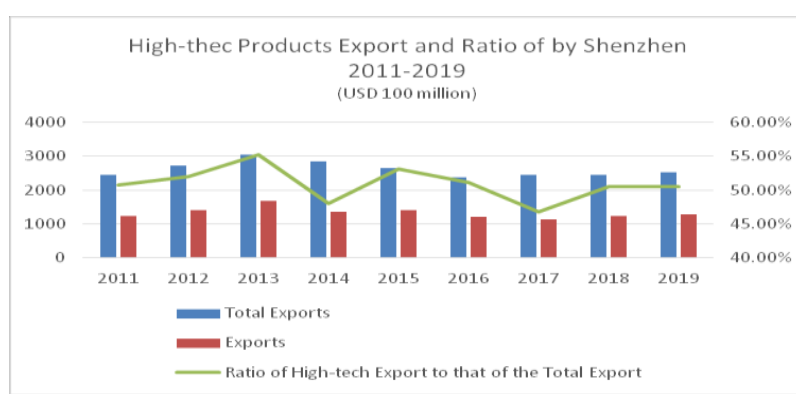

Figure 1. High-tech Products Export and Ratio of by Shenzhen20112019. (Data source: statistical bulletin of Shenzhen's annual national economic and social development from 2011 to 2019)

According to the trade export data from 2011 to 2019, the trade scale of high-tech products in Shenzhen has been fluctuating. And from Figure 1, in 2011, Shenzhen's high-tech trade developed rapidly, and the export volume of products reached 124.8 billion US dollars. During the period from 2012 to 2013, the export of high-tech products grew rapidly, recovered rapidly and exceeded the level before the financial crisis. In 2013, the export scale reached a record high, reaching a new level of export volume of US $\$ 169.006$ billion. In 2015, the export volume of high-tech products dropped sharply due to the impact of the exit of the UK and the return of US manufacturing industry, the rise of trade protectionism and the Sino US trade war. Subsequently, since 2016, the growth trend has been stable, and the total export volume of high-tech products has been rising. At present, high

\footnotetext{
ae-mail: 446128161@qq.com

be-mail: luoming8654@163.com
} 
and new technology is developing and popularizing rapidly, which provides more effective support for the rapid development of high and new technology industry. The industrial structure extends to the high-end of the value chain, and the high-tech manufacturing industry has become the driving force of Shenzhen's industrial connotative growth. In 2019, the export of high-tech products reached US $\$ 127.971$ billion, accounting for
$50.58 \%$; the export of mechanical and electrical products reached US \$185.275 billion, accounting for $75.9 \%$.

TABLE I. High-tech Products Export and Ratio of by Shenzhen2011-2019 (USD 100 million)

\begin{tabular}{|c|c|c|c|c|c|c|c|c|c|}
\hline Year & 2011 & 2012 & 2013 & 2014 & 2015 & 2016 & 2017 & 2018 & 2019 \\
\hline $\begin{array}{c}\text { Total } \\
\text { Exports }\end{array}$ & 2455.18 & 2713.62 & 3057.02 & 2843.62 & 2640.39 & 2375.47 & 2443.58 & 2463.35 & 2529.86 \\
\hline Exports & 1248 & 1412.2 & 1690.06 & 1367.41 & 1403.38 & 1215.43 & 1142.02 & 1246.07 & 1279.71 \\
\hline $\begin{array}{c}\text { Ratio of } \\
\text { H-t } \\
\text { Export to } \\
\text { that of the } \\
\text { Total } \\
\text { Export }\end{array}$ & $50.83 \%$ & $52.04 \%$ & $55.28 \%$ & $48.09 \%$ & $53.15 \%$ & $51.17 \%$ & $46.74 \%$ & $50.58 \%$ & $50.58 \%$ \\
\hline
\end{tabular}

\section{SHENZHEN HIGH-TECH MANUFACTURING INDUSTRY PROVIDES SUPPORT FOR THE TRANSFORMATION AND UPGRADING OF FOREIGN TRADE}

At the beginning of the city's establishment, Shenzhen's industrial base was "poor and blank". Since the development and construction of Shekou export industrial processing zone, Shenzhen's industry has taken off, from small to large, from weak to strong, from closed and backward to open innovation. From 1979 to 2019, Shenzhen's industrial added value developed rapidly with an average annual growth rate of $31.34 \%$, creating a miracle in the history of world industrial development.

Shenzhen is a city driven by scientific and technological innovation, so the number of national hightech enterprises has been growing steadily. In 2018, there were 5407 new national high-tech enterprises in Shenzhen, and the total number of national high-tech enterprises reached 14400, ranking the second in China's cities and the first in Guangdong Province. The construction of modern economic system and the highquality development of real economy have achieved remarkable results, with electronic information system The contribution rate of manufacturing industry to the industrial growth of the city has reached $78 \%$, and the contribution rate of top 100 industrial enterprises to the industrial growth above the scale has exceeded $90 \%$.

High and new technology has a far-reaching impact on the political, economic and military progress of a country or a region, and can form an advanced industrial technology group. The proportion of high-tech enterprises in the total number of industrial enterprises and software enterprises above the scale of the city can be used to reflect the technological content of enterprises in a city to a certain extent. At present, compared with many cities in the Pearl River Delta, scientific and technological content of enterprises of Shenzhen is generally high. Therefore, in order to improve the overall quality of high-tech enterprises, the Shenzhen municipal government and enterprises regard high-tech enterprises as a baton, continuously increase the investment in hightech, and guide the local growing enterprises in Shenzhen to become the backbone of technological innovation, so as to strengthen the development potential of enterprises.

On the whole, the development of high-tech enterprises in Shenzhen is in a stage of rapid growth. Since 2011, the scale of high-tech enterprises in Shenzhen has been expanding. With the emergence of more and more high-tech enterprises and the increasing investment in science and technology, the export of hightech products has been promoted, which is the biggest driving force for the rapid trade of high-tech products. At the same time, with the support of a series of good policies and laws and regulations from the government, the market environment of the high-tech industry has gradually improved, and the high-tech enterprises in Shenzhen have maintained a continuous expansion trend.

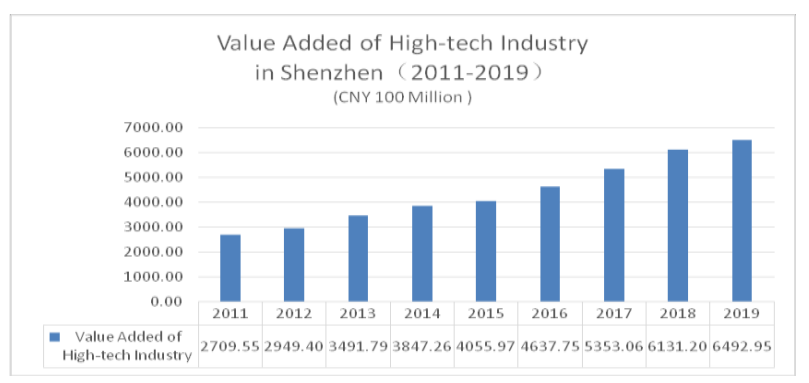

Figure2. Value Added of High-tech Industry in Shenzhen

\section{Note: data source: GUANGDONG STATISTICAL YEARBOOK 2012-2019}

In 2019, the added value of industries above Designated Size in Shenzhen was CNY 953.769 billion, a year-on-year increase of $4.7 \%$, ranking first in China's large and medium-sized cities for two consecutive years, becoming the only city in China whose added value of industries above Designated Size exceeded CNY 900 billion. Among them, the added value of high-tech manufacturing industry is respectively CNY 649.295 billion, accounting for $68.08 \%$ of the added value of industries above designated size. The growth rate is 1.2 percentage points higher than that of industries above Designated Size in the same period, and the contribution 
rate to the growth of industries above Designated Size in the city is $86.8 \%$, which is the main driving force for the export of high-tech products in Shenzhen. In particular, the high-tech manufacturing industry with rapid growth in added value includes computer, communication and other electronic equipment manufacturing industry, with an increase of $14.0 \%$; special equipment manufacturing industry, with an increase of $10.0 \%$; automobile manufacturing industry, with an increase of $12.4 \%$; and pharmaceutical manufacturing industry, with an increase of $25.0 \%$.

TABLE II. Industrial output value of high-tech industries in Shenzhen (2015-2019)

\begin{tabular}{|c|c|c|c|c|c|c|}
\hline Industry classification & unit & 2015 & 2016 & 2017 & 2018 & 2019 \\
\hline Total & \multirow{7}{*}{$\begin{array}{c}\text { CNY } 100 \\
\text { million }\end{array}$} & 17296.87 & 19222.06 & 21378.78 & 23871.71 & 26277.98 \\
\hline $\begin{array}{l}\text { 1. Electronics and } \\
\text { information industry }\end{array}$ & & 15269.85 & 17096.1 & 19110.44 & 21445.74 & 23723.11 \\
\hline $\begin{array}{l}\text { 2. Biological and } \\
\text { pharmaceutical industries }\end{array}$ & & 358.93 & 367.07 & 376.36 & 401.38 & 416.44 \\
\hline $\begin{array}{l}\text { 3. Advanced manufacturing } \\
\text { industry }\end{array}$ & & 790.7 & 844.31 & 921.4 & 1007.45 & 1080.49 \\
\hline 4. New energy industry & & 537.05 & 548.76 & 560.61 & 573.96 & 584.8 \\
\hline 5. New material industry & & 245.64 & 255.88 & 27939 & 288.02 & 291.65 \\
\hline $\begin{array}{l}\text { 6. Other high-tech } \\
\text { industries }\end{array}$ & & 94.7 & 109.94 & 130.59 & 155.16 & 181.49 \\
\hline
\end{tabular}

After 40 years of development, Shenzhen's industrial structure has been continuously optimized and adjusted, realizing the transformation from traditional industries to advanced manufacturing industries with high technology content. In 2019, the industrial output value of Shenzhen's high-tech industry was CNY 2627.798 billion, an increase of $51.92 \%$ over 2015 , with an average annual growth of $11.02 \%$. Among them, the electronic and information industry is CNY 23723.1 billion, an increase of $55.36 \%$, with an average annual growth of $11.64 \%$; the biological and pharmaceutical industry is CNY41.644 billion, an increase of $16.02 \%$, with an average annual growth of $3.79 \%$; the advanced manufacturing industry is CNY108.049 billion, an increase of $36.65 \%$, with an average annual growth of $8.12 \%$; the new energy industry is CNY 58.48 billion, an increase of $8.89 \%$, with an average annual growth of $2.15 \%$; the new material industry is CNY 29.165 billion, up $18.73 \%$, with an average annual growth of $4.39 \%$; other high-tech industries, up $91.65 \%$, with an average annual growth of $17.66 \%$. The structure of manufacturing industry is continuously converging to the electronic information manufacturing industry. In 2019, the total output value of the electronic and information manufacturing industry accounted for $90.28 \%$. Founded in 1987 , Huawei started from program-controlled switch, and now it has become the world's leading information and communication infrastructure and intelligent terminal provider, and entered the brand in 2017 Finance is one of the top 500 global brand values; BYD, founded in 1995, started from batteries and mobile phone parts, through independent $\mathrm{R}$ $\& \mathrm{D}$, production and transformation, currently involves electronics, automobile, new energy and rail transit, and its new energy vehicle production ranks the top in the world; established in 2006, relying on innovative technology, DJI has developed camera aircraft integrated UAV. In 2012, the world's first aerial camera "phantom1" was launched, which triggered the public demand in the field of UAV aerial photography, and constantly realized product upgrading in the research and development. At present, it has become a global leading brand in the field of civil UAV. In addition, there are ZTE, FIYTA, TIANWANG, EBOHR, KONKA, Skyworth, Belle, FUANNA, MINDRAY, Han laser, TIANMA micro and many other leading domestic famous brands in various industries.

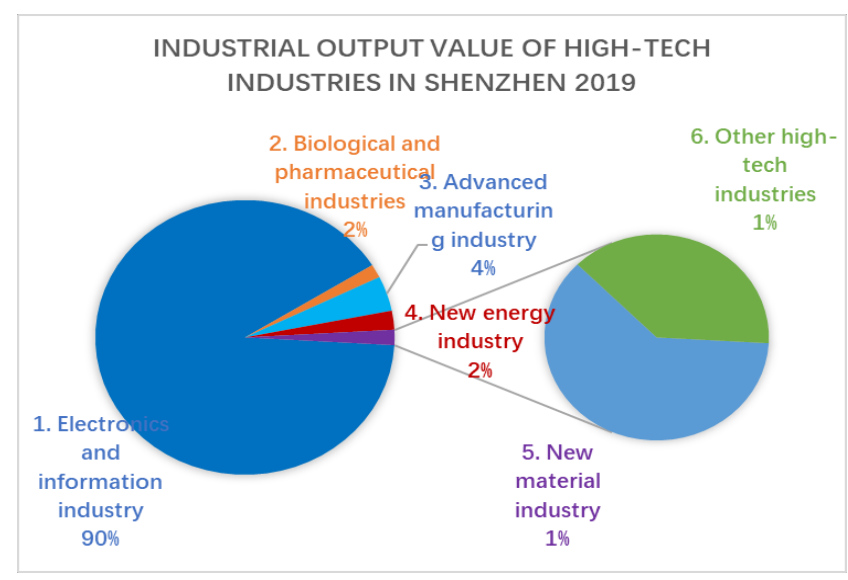

Figure 3. Industrial output value of high-tech industries in Shenzhen 2019

\section{INVESTMENT IN SCIENCE AND TECHNOLOGY IS THE DRIVING FORCE FOR THE DEVELOPMENT OF HIGH-TECH ENTERPRISES}

\section{A. $R \& D$ investment keeps growing, injecting vitality into high-quality development of manufacturing industry}

The R\&D investment of manufacturing enterprises above Designated Size in Shenzhen has maintained a rapid growth. In 2018, $\mathrm{R}$ \& $\mathrm{D}$ expenditure of manufacturing enterprises above designated size was $968.35,1.49$ times higher than that in 2011, with an average annual growth of $13.92 \%$; R \& D strength has been continuously enhanced, and the number of scientific and technological activities of manufacturing enterprises 
above designated size was 435390 In 2018, R \& D expenditure of manufacturing enterprises above Designated Size accounted for $2.92 \%$ of the main business income, an increase of 0.99 percentage points over 2011. In 2018, manufacturing enterprises above Designated Size in Shenzhen achieved new product output value of CNY 1284.202 billion, an increase of 1.23 times over 2011, with an average annual growth of $12.15 \%$.

Industrial enterprises continue to enhance their ability of independent innovation and inject new impetus into industrial development and quality improvement. More than $90 \%$ of the R \& D funds in Shenzhen come from enterprises, and about $90 \%$ of them come from industrial enterprises. In 2018, the R \& D expenditure of industries above Designated Size exceeded CNY 90 billion, accounting for $82.22 \%$ of Shenzhen's R \& D expenditure. The number of industrial enterprises with $R$ \& $D$ activities reached 3489, an increase of 2648 over 2011, an increase of 3.15 times, with an average annual growth of $22.54 \%$.

TABLE III. SCIENTIFIC AND TECHNOLOGICAL ACTIVITIES OF INDUSTRIAL ENTERPRISES ABOVE DESIGNATED SIZE

\begin{tabular}{|c|r|r|r|r|r|r|r|r|}
\hline & 2011 & \multicolumn{1}{|c|}{2012} & 2013 & 2014 & 2015 & 2016 & 2017 & 2018 \\
\hline $\begin{array}{c}\text { Number of Enterprises } \\
\text { Having R\&D Activities } \\
\text { (unit) }\end{array}$ & 841 & 928 & 1009 & 1181 & 1304 & 2117 & 3507 & 3489 \\
\hline $\begin{array}{c}\text { Number of Enterprises } \\
\text { Having R\&D } \\
\text { Institutions (unit) }\end{array}$ & 673 & 482 & 457 & 542 & 830 & 2147 & 3562 & 4348 \\
\hline $\begin{array}{c}\text { Expenditure on Science } \\
\text { and Technology Funds } \\
\text { (USD 100 million) }\end{array}$ & 623 & 689 & 785 & 994.1 & 1171 & 1235 & 1509 & 1723 \\
\hline $\begin{array}{c}\text { Expenditure on R\&D } \\
\text { (USD 100 million) }\end{array}$ & 389 & 462 & 533 & 588.4 & 672.7 & 760 & 841.1 & 968.4 \\
\hline $\begin{array}{c}\text { Percentage of } \\
\text { Expenditure on R\&D to } \\
\text { Sales Revenue(\%) }\end{array}$ & 1.93 & 2.2 & 2.39 & 2.45 & 2.69 & 2.84 & 2.73 & 2.92 \\
\hline
\end{tabular}

The continuous investment of Shenzhen enterprises in technological innovation and R \& D is the source of maintaining high-quality development of Shenzhen economy and seizing the commanding point for future development. DJI ranks 35 th in the list of "the most innovative enterprises in the world in 2018" released by fast company, a famous American business magazine. HUAWEI insists on investing $10 \%-15 \%$ of its annual revenue in $\mathrm{R} \& \mathrm{D}$, which has become the first enterprise in China to rank among the top 50 in global R \& D expenditure, and plays an important role in the development of China's communication technology from $2 \mathrm{G}$ to $5 \mathrm{~g}$. HUAWEI is relying on more than 30 years of constant emphasis on technological innovation and research and continuous development. In 2017, HUAWEI entered the top 100 Fortune Global 500 companies, and in 2018 , it rose to the 72 nd place, 213 places higher than in 2014.

\section{B. Product iteration accelerates, new and high-tech products continue to emerge}

With the adjustment of the internal structure of the manufacturing industry to the emerging industry with high technology content, a group of manufacturing enterprises at the low end of the value chain have been shut down, eliminated, transferred or upgraded, and the product structure of the main manufacturing industry in Shenzhen has also been adjusted, with the high-tech products growing rapidly from scratch and from small to large. In 2018, the output of mobile communication base station equipment in Shenzhen was 424.276 million channels, 9900 new energy vehicles, 5.4185 million satellite navigation and positioning receivers, 308.7773 million mobile communication handsets (mobile phones),
2.945 million civil UAVs, 21283 industrial robots, 98.6167 million TV reception set-top boxes, 9.888 billion semiconductor discrete devices, 25.511 billion integrated circuits, liquid crystals There are 1.108 billion display screens, 150.117 billion electronic components, 12.4071 million kilometers of optical fiber, 89.19 million solar cells (photovoltaic cells) of $239361.49 \mathrm{~kW}$ for servers, and 12095.63 tons of graphite and carbon products.

\section{SCIENTIFIC AND TECHNOLOGICAL INNOVATION IS THE SUPPORT OF THE DEVELOPMENT OF HIGH-TECH INDUSTRY}

Shenzhen has initially established an innovation carrier system featuring open cooperation with enterprises as the main body and private official assistance, with basic research as the guide, industry and marketization as the guide. The basic research system with the key laboratory as the core, the technological development and innovation system composed of the engineering laboratory, the engineering center and the technology center, and the innovation service support system composed of the technological innovation service platform and the industry public technological service platform constitute the three fulcrums of Shenzhen's technological innovation system.

Now there are 1670 state, provincial and municipal key laboratories, engineering laboratories, engineering centers, enterprise technology centers and other innovative carriers. Four post doctoral mobile stations, 103 workstations, 209 innovation and practice bases, 23 skill master studios, 103 technician workstations and 148 high skill talent training bases were established. In 
addition, 93 new $\mathrm{R}$ \& $\mathrm{D}$ institutions integrating basic research, applied technology development and industrial project incubation have been built, 7 overseas innovation centers have been set up in the areas where overseas innovative talents gather, 5 national level overseas highlevel talents innovation and entrepreneurship bases, 4 national level innovation and entrepreneurship demonstration bases and 10 municipal level innovation and entrepreneurship bases have been built.

In addition, Shenzhen's scientific and technological innovation and industrial innovation are active, and the development of high-tech industry has become a national flag. The proportion of social R \& D investment in GDP, PCT international patent application volume are leading in the country, and the development of digital economy is in the forefront of the country. In 2018, 69969 invention patents were applied for, an increase of 1.43 times over 2011 , with an average annual growth of $13.51 \% ; 21309$ authorized invention patents, an increase of $80.29 \%$ over 2011 , with an average annual growth of $8.78 \%$; and 18081 PCT international patent applications, an increase of 1.28 times over 2011, with an average annual growth of $12.49 \%$.

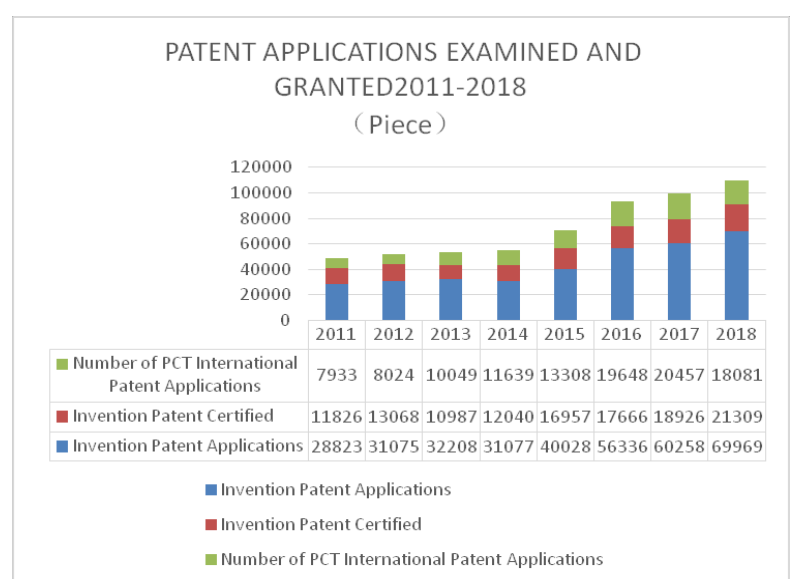

Figure 4. PATENT APPLICATIONS EXAMINED AND GRANTED 2011- 2018

While building the platform, Shenzhen has accelerated the convergence of global innovation resources, walked out a replicable and popularized innovation path of "European and American technology, surrounding resources, Guangdong costs, domestic market", and has formed an innovation cluster absorbing global resources. Shenzhen's foreign investment stock has been leading in large and medium-sized cities in China for a long time, with more than 2000 enterprises investing in more than 120 countries and regions around the world. HUAWEI, ZTE, CIMC, BYD and other enterprises with independent intellectual property rights have made global layout in technology innovation, production outsourcing, market development, marketing services and other fields. We will build a "Shenzhen Hong Kong Innovation Circle", promote scientific and technological cooperation between Guangdong, Hong Kong and Macao, and promote the sharing of innovative resources such as R \& D facilities and testing platforms between Shenzhen and Hong Kong. Our ultimate goal is to integrate global innovation resources and attract a large number of multinational companies and international research institutions to set up R \& D centers in Shenzhen.

\section{ConClusion}

The progress of science and technology is often an important manifestation of a country's comprehensive national strength. The high-tech export products can be said to be the economic lifeline of Shenzhen and the propeller of the progress and development of science and technology in Shenzhen. Shenzhen, as a developed area in the Pearl River Delta, must make a great breakthrough in the field of high technology. Although Shenzhen's high-tech export products industry started late, its development speed is fast and it is trying to get rid of foreign monopoly and shadow. It is moving towards independence, but there are still many problems in its development.

In general, it is necessary to carefully analyze the competitiveness of Shenzhen's high-tech export products and take various measures from different levels to develop the export trade of high-tech products, actively participate in international negotiations with foreign countries, strive for the right to speak for the establishment of international trade rules, increase domestic support for high-tech industries, encourage independent innovation of high-tech enterprises, and promote high-tech independence. Enterprises should make full use of the state's support policies, adhere to innovation, vigorously cultivate innovative talents, actively seek transformation and upgrading paths for enterprises, and enhance the core competitiveness of enterprises and products.

\section{REFERENCE}

1. Zhou Changzhou. Research on the impact of scientific and technological innovation on the export competitiveness of hightech products in China $[\mathrm{J}]$. Science and technology innovation guide, 209,16 (16) : $241+243$

2. QIU Shilei, WU Zongjie, DONG Huizhong.Empirical Analysis on Factors of China's High-tech Products Export Based on VAR Model [J].Science and Technology Management Research,2017,37(11):105-111.

3. Wang yu-nan. Empirical study on the impact of technological innovation on China's high-tech exports[J].Economic Research Guide,2013 (23):248-251+261.

4. Shang Xiaoli. A Research on the Influential Factors of China's High-tech Products Export[D].Hebei University of Economics and Business, 2013 .

5. Wang Tiantian. The empirical evidence for the impact of hightech industry agglomeration on the export trade in Jiangsu[D]. East China Normal University,2013. 